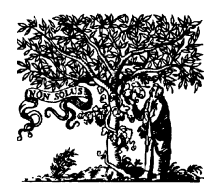

ELSEVIER

\title{
From layer compounds to catalytic materials
}

\author{
Soofin Cheng \\ Department of Chemistry, National Taiwan University, Taipei 106, Taiwan
}

\begin{abstract}
This paper intends to review some important directions in which layered compounds have been used as catalysts or converted to catalytic materials. Since several excellent review papers of related topics have already presented in the literatures, duplication of the contents is tried to avoid. Clays are the layered compounds which attracted most of the attention since modified clays and pillared clays have been used and examined as catalysts for more than half a century. Although the use of pillared clays as cracking catalysts was considered to be impractical nowadays, they still demonstrated catalytic activities in many reactions, beneficial from the large porous structures, acidity or other functionality endowed by the pillars. The pillaring technique has also been employed to other layered compounds, especially metal oxides, in which organicexpanded derivatives were often used as the precursor. The applications of the pillared metal oxides in catalysis are also described. Correlatively, some of the organic-expanded layered metal oxides were found to disperse as separated sheets in organic solutions and could serve as a precursor for making monolayer-dispersed supported catalysts. At last, attention is brought to the possibility of transformation of laminar compounds of thin layers into ordered structures of micropores and mesopores under the influence of interlayer template species. That offers a route to make new porous materials, which may not be easily obtained by other methods. (C) 1999 Elsevier Science B.V. All rights reserved.
\end{abstract}

Keywords: Layer compounds; Catalytic materials; Pillaring; Clays; Porous structures

\section{Introduction}

Layered compounds have been closely related to catalysis since the beginning of petrochemical industry. The first hydrocracking process came on stream with acid-treated clays in 1936 [1-3]. Although the role of clays as cracking catalysts was replaced by zeolites and aluminosilicates in 1964 [4], salt-loaded, acid-treated and ion-exchanged clays were still found to be efficient catalysts in many organic reactions $[5,6]$. Some important results in this aspect are indicated. The oil embargo in 1973 acted as a stimulus for the investigation and development of pillared interlayered clays (shortly terms as PILCs) [7]. The PILCs, obtained by introducing bulky inorganic pillars in between the layers, own porous structures of diameter larger than that of zeolites and acidity as strong as Yzeolite. These materials demonstrate high activity in cracking process and a selectivity for larger product molecules $[8,9]$. On this topic, a special issue was published in Catalysis Today [10] and a review was given by Figueras [11]. However, the original objective of making these materials as catalysts for FCC was unsuccessful due to their low hydrothermal stability. Nevertheless, the investigation of PILCs has been continued, especially in their applications to organic reactions catalyzed by acidity as well as other functionality endowed by the pillar species. Furthermore, the pillaring technique has also been employed to many other layer compounds, with either positive or 
negative layer charges. It provides a route to prepare microporous materials with tunable chemical properties, achieved by mediating the chemical compositions of the basal sheets and pillars. Finally, two new directions in transformation of layered compounds into catalytic materials are pointed out. Through organic intercalation, many of the layered metal oxides can disperse in organic solutions as separated sheets. They can serve as precursors to prepare supported catalysts of monolayer coverage. On the other hand, increasing attention has been received on the structural transformation of thin layer compounds into ordered micropores and mesoporous materials in the presence of template agents. Examples were demonstrated on manganese oxide of channel pore structures as well as the folded sheet mesoporous silica and aluminophosphate.

\section{Overview of layer compounds}

A great variety of compounds own layer structures. The layers may be electrically neutral, bonded together by van der Waals or hydrogen bonds, or charged. The structure of layer itself can range from simple planar network of atoms (e.g. graphite, white $\mathrm{BN}$ ), through numerous layers formed from tetrahedral or octahedral coordination groups, to the multiple layers in talc and related aluminosilicates [12]. In the field of catalysis, layer compounds which include foreign atoms, ions, or complexes in between the layers are most commonly encountered. Smectite clays, double hydroxides, metal intercalated graphite and various complex transition metal oxides all belong to this category. Among them, clays and related silicates have attracted most of the attention concerning the development of layered compounds as catalysts in laboratory as well as their application to industrial processes. Layered metal oxides however have gradually emerged as important resources for the preparation of potential catalysts.

\section{Acid-treated, ion-exchanged and metal salts-loaded clays}

The acidity of clays is comparable to that of aluminosilicates and zeolites since historically acid- treated clays were used as cracking catalysts before synthetic aluminosilicates and zeolites were introduced into this process [2,3]. Although clays lost their role as catalysts in industrial cracking process since 1964 , the study of clays in catalysis is never discontinued. During the 1980s, Thomas and co-workers [13] conducted a series of research on the acid-catalyzed reactions over metal ion-exchanged clays. They demonstrated the predominant activity of these materials over mineral acids. Because the acidity of the ionexchanged clays is mainly attributed to the protons dissociated from the water molecules coordinated to the metal ions, their application is limited to low temperature reactions, where the hydration water can be retained. The catalytic study also expanded to redox reactions, such as Wacker reaction and 2,6dimethylphenol to its quinone derivatives, over transition metal ion-exchanged clays [14]. In the past 15 years, there has been a revived interest in using clays, especially metal salt-loaded clays, as catalysts in organic reactions. The acid-treated and ion-exchanged clays contain mainly Bronsted acidic sites, while the metal salt-loaded clays provide Lewis acid sites. The substitution of liquid corrosive acids by these solids as catalysts is stimulated by the convenience in separation and the protection of environment. However, the use of solid catalysts has changed the reaction mechanisms [5,15]. The organic species adsorbed by clay sheets are constrained to diffuse in twodimensional space instead of a three-dimensional volume. This increases the encounter frequencies between reactants, and boosts the rate to four or five order. In many cases, lower reaction temperature was needed and better selectivities of the desired products were observed [6,16-19]. Some of the reactions drawing benefit from catalysis by modified clays include Diels-Alder cycloaddition, Michael additions [6], protection-regeneration of carbonyls [16,20], and electrophilic aromatic substitutions such as nitration [6,17], chlorination [6], Friedel-Crafts alkylation and acylation $[18,19]$.

\section{Pillared clays}

In the search for materials having large pores, which could accommodate and crack large molecules, pillared interlayered clays (PILCs) were considered as 
Table 1

Idealized structural formulas for some dioctahedral and trioctahedral 2:1-phylosilicates ${ }^{\mathrm{a}}$ [11]

\begin{tabular}{lll}
\hline Mineral & $\mathrm{Ideal} \mathrm{formula}^{\mathrm{b}}$ & $\mathrm{CEC}^{\mathrm{c}}\left(\mathrm{meq}^{\left.100 \mathrm{~g}^{-1}\right)}\right.$ \\
\hline $\begin{array}{l}\text { Dioctahedral minerals } \\
\text { Pyrophyllite }\end{array}$ & $\mathrm{Al}_{2}\left(\mathrm{Si}_{4} \mathrm{O}_{10}\right)(\mathrm{OH})_{2}$ & 0 \\
Montmorillonite & $\mathrm{Na}_{x}\left(\mathrm{Al}_{2-x} \mathrm{Mg}_{x}\right)\left(\mathrm{Si}_{4} \mathrm{O}_{10}\right)(\mathrm{OH})_{2} \cdot z \mathrm{H}_{2} \mathrm{O}$ & $60-120$ \\
Beidellite & $\mathrm{M}_{x}\left(\mathrm{Al}_{2}\right)\left(\mathrm{Al}_{x} \mathrm{Si}_{4-x} \mathrm{O}_{10}\right)(\mathrm{OH})_{2} \cdot z \mathrm{H}_{2} \mathrm{O}$ & $60-120$ \\
Nontronite & $\mathrm{M}_{x}\left(\mathrm{Fe}^{3+}, \mathrm{Al}_{2}\left(\mathrm{Al}_{x} \mathrm{Si}_{4-x} \mathrm{O} \mathrm{O}_{10}\right)(\mathrm{OH})_{2} \cdot z \mathrm{H}_{2} \mathrm{O}\right.$ & $60-120$ \\
& & \\
Trioctahedral minerals & & 0 \\
Talc & $\mathrm{Mg}_{3}\left(\mathrm{Si}_{4} \mathrm{O}_{10}\right)(\mathrm{OH})_{2}$ & $60-120$ \\
Hectorite & $\left(\mathrm{Na}_{2} \mathrm{Ca}_{x / 2}\left(\mathrm{Li}_{x} \mathrm{Mg}_{3-x}\right)\left(\mathrm{Si}_{4} \mathrm{O}_{10}\right)(\mathrm{OH})_{2} \cdot z \mathrm{H}_{2} \mathrm{O}\right.$ & $60-120$ \\
Saponite & $\mathrm{Ca}_{x / 2} \mathrm{Mg}_{3}\left(\mathrm{Al}_{x} \mathrm{Si}_{4-x} \mathrm{O}_{10}\right) \cdot z \mathrm{H}_{2} \mathrm{O}$ & \\
Sauconite & $\mathrm{M}_{x}\left(\mathrm{Zn}_{2} \mathrm{Mg}_{3}\left(\mathrm{Al}_{x} \mathrm{Si}_{4-x} \mathrm{O}_{10}\right) \cdot z \mathrm{H}_{2} \mathrm{O}\right.$ & \\
\hline
\end{tabular}

${ }^{\mathrm{a} O n l y}$ major cations are shown.

${ }^{\mathrm{b}} x$ depends on the origin of the mineral; montmorillonites can show a degree of substitution $x$ in the octahedral sheet in the range $0.05-0.52$. Natural samples generally show substitutions in both octahedral and tetrahedral sheets, which renders the real situations more complex.

${ }^{\mathrm{c}}$ Cation-exchange capacity.

one of the important candidates for this specific purpose. These materials were reported to have strong acidity, large pore sizes and thermally stable up to $600^{\circ} \mathrm{C}$ [21]. Many of them are active as cracking catalysts. However, due to the tendency of structural collapse under hydrothermal conditions [22,23], they are not as yet used in practical cracking process. Nevertheless, these pillared clays still demonstrate great potential as catalysts, especially in acid-catalyzed reactions [11,24-27].

\subsection{Nature of the clays used for pillaring}

Layered silicates of the smectite class, especially montmorillonite, beidellite, hectorite and saponite, are naturally occurring clays commonly utilized in the preparation of pillared clays. Table 1 shows the structural formulas for some dioctahedral and trioctahedral 2:1-phylosilicates [11]. The basal sheet of 2:1-phylosilicates contains four sheets of oxygen atoms, which form two layers of tetrahedra sandwiching a layer of octahedra $[28,29]$. The octahedral layer generally contains $\mathrm{Al}^{3+}, \mathrm{Mg}^{2+}$ and $\mathrm{Fe}^{3+}$ ions, and the tetrahedral layer usually contains $\mathrm{Si}^{4+}$. The basal layer thickness is ca. $9 \AA$. In smectite clays, a net negative charge is developed when either $\mathrm{Mg}^{2+}$ substitution for $\mathrm{Al}^{3+}$ within the octahedral layer or $\mathrm{Al}^{3+}$ substitution for $\mathrm{Si}^{4+}$ within the tetrahedral layer occurs. The negative charge is balanced by exchangeable cations that reside within the intralamellar region formed by two clay platelets. Other than the smectite clays, Guan and coworkers [30-32] prepared the pillared derivatives of a special clay named "rectorite" with thick basal layer made of 1:1 inter-stratification of mica-like and montmorillonite-like layers. The pillared derivatives of this extra-thick clay was reported to have thermal and hydrothermal stability similar to that of Faujasite zeolites.

\subsection{Pillaring technique and the properties of PILCS}

The preparation of PILC is based on the swelling property of smectites [11]. The exchangeable cations of smectites can be replaced with other cationic species. Such an exchange can be easily accomplished by swelling the clay in any suitable polar solvents, usually water or alcohol, to form a suspension and mixing the desired replacement cations with this suspension. Polyoxocations of aluminum are the most often used cations for pillaring. Other inorganic polyoxocations often been used are made from the nitrate or chloride salts of transition metals such as zirconium, iron, chromium, or titanium. The large polyoxocations are thought to cross-link with the basal layers through condensation of the hydroxyl groups after calcination at temperatures above $400^{\circ} \mathrm{C}$ and result in a stable porous network that is similar to the structure of zeolites. Depending on the pillar species used, the resultant PILCs have their interlayer 
Table 2

$\mathrm{CO}$ hydrogenation over supported Fe catalysts

\begin{tabular}{|c|c|c|c|c|c|}
\hline Catalyst & $\mathrm{Fe}$ & Fe/ZSM-5 & Fe/Al-PILC & Fe/Zr-PILC & Fe/Ti-PILC \\
\hline $\mathrm{CO}$ conversion $(\mathrm{mol} \%)$ & 68.1 & 80.1 & 67.7 & 62.8 & 84.9 \\
\hline CHs selectivity (mol\%) & 57.4 & 57.3 & 57.4 & 56.8 & 61.5 \\
\hline \multicolumn{6}{|l|}{ CHs composition (wt\%) } \\
\hline $\mathrm{C}_{1}$ & 13.6 & 29.3 & 17.5 & 21.0 & 19.0 \\
\hline $\mathrm{C}_{2}$ & 17.7 & 7.3 & 14.6 & 15.6 & 16.8 \\
\hline $\mathrm{C}_{3}$ & 20.4 & 12.2 & 19.2 & 21.2 & 20.0 \\
\hline $\mathrm{C}_{4}$ & 13.4 & 19.4 & 14.2 & 13.2 & 13.3 \\
\hline $\mathrm{C}_{5}+$ & 13.9 & 16.1 & 33.3 & 28.8 & 30.1 \\
\hline Aromatics & - & 15.7 & 1.2 & 0.2 & 0.8 \\
\hline Wax & 16.8 & - & - & - & - \\
\hline
\end{tabular}

Rxn condition: $300^{\circ} \mathrm{C} ; 50 \mathrm{~atm} ; \mathrm{CO} / \mathrm{H}_{2} \mathrm{~mol}$ ratio $=1$.

free spacings expanded to $4-20 \AA$ and surface area increased to $200-400 \mathrm{~m}^{2} \mathrm{~g}^{-1}$ [21]. Different from zeolites, the pore size of PILCs is not unity and the pore size distribution is dependent on the calcination temperature [33]. At temperatures higher than ca. $700^{\circ} \mathrm{C}$, a portion of the microporous structures collapses and results in larger pores. Nevertheless, PILCs calcined at $400-500^{\circ} \mathrm{C}$ behave as bidimensional molecular sieves and are able to adsorb large organic molecules such as 1,3,5-trimethylbenzene $(7.6 \AA$ in diameter) [21]. Al-PILC (clays pillared with aluminum Keggin's ions) calcined at $400^{\circ} \mathrm{C}$ were found to have both Lewis and Bronsted acid sites, with a higher proportion of Lewis acid sites [34]. The amount of acid sites in Al-PILC based on $\mathrm{NH}_{3}$ adsorption increases with the number of pillars incorporated in between the layers and is comparable to CeY-zeolite, namely 1.6-2.8 $\mathrm{mol} \mathrm{NH}_{3} \mathrm{~m}^{-2}$ versus $3 \mathrm{~mol} \mathrm{NH}_{3} \mathrm{~m}^{-2}$ for the zeolite. With proper treatment, the acid strength of Al-PILC could be as high as that of Yzeolite, based on the IR spectroscopic study of pyridine adsorption $[33,35]$.

\subsection{Catalytic applications}

It was found that if the cationic species itself was catalytically active, the resultant PILC would generally also be catalytically active. Most of the reactions using PILC as a catalyst takes the advantage of its porous structures and acid characters. These reactions include oil refining, methanol conversion, methylation of trimethylbenzene, alkylbenzene disproportion [25,36,37], esterification of aliphatic alcohols [38] and dehydration of glucose $[39,40]$. PILCs usually show better product selectivities for large molecules. Recently, the acidity of transition metal pillared clays were also reported to contribute to the para-selectivity for nitration of chlorobenzene [41].

PILCs with high surface area can also be used as a support for metal catalysts to achieve homogeneous dispersion, increased adsorption area of reactants and shape-selectivity. Table 2 shows the catalytic activities and product distribution of Fe supported on three pillared montmorillonite clays and HZSM-5, prepared by physically mixing of $\mathrm{Fe}_{2} \mathrm{O}_{3}$ and the supports, in comparison with that of plain Fe catalyst [42]. Shapeselectivity is demonstrated on the PILCs as well as on ZSM- 5 by the increase in gasoline range products and the suppression of high molecular weight waxy products. The results that only little amount of aromatics was obtained over the PILC catalysts were accounted for by that PILCs have weaker acidity than ZSM-5.

The pillar itself may incorporate second functionality in catalytic reactions. The utilization of clays pillared with transition metal oxides have extended to reactions such as dehydrogenation of cyclohexane to benzene [43], hydrogenation of edible oils [44], Fischer-Tropsch synthesis [45,46], hydrotreating [47], selective catalytic reduction of NO [48], hydrodesulfurization of thiophenes [49] and selective organic transformation [50-52]. On the other hand, the photochemical and photocatalytic properties of TiPILC have also attracted great attention. The pillared $\mathrm{TiO}_{2}$ microcrystallites have ca. $8-15 \AA$ pillar height $[42,53]$, strongly dependent on the preparation method. Its absorption and fluorescence spectra show 
Table 3

Rate (in unit of mol min ${ }^{-1} \mathrm{gTiO}_{2}$ ) of $\mathrm{CO}_{2}$ formation in photo-degradation of phenyl pollutants in aqueous solutions over TiO 2 and Ti-PILC

\begin{tabular}{|c|c|c|c|c|c|}
\hline \multirow[t]{2}{*}{ Pollutant } & \multirow[t]{2}{*}{ Initial pollutant conc. (mM) } & \multirow[t]{2}{*}{$\mathrm{O}_{2}$ flow rate $\left(\mathrm{ml} \mathrm{min}^{-1}\right)$} & \multirow[t]{2}{*}{ Ti-PILC } & \multicolumn{2}{|l|}{$\mathrm{TiO}_{2}$} \\
\hline & & & & Anatase & Rutile \\
\hline Benzene & 0.5 & 2 & 4.29 & 1.90 & 2.53 \\
\hline Chlorobenzene & 0.5 & 2 & 5.30 & 3.17 & 3.66 \\
\hline 1,2-Dichlorobenzene & 0.5 & 2 & 6.36 & 3.49 & 4.80 \\
\hline Phenol & 10 & 10 & 2.22 & 7.08 & 2.50 \\
\hline
\end{tabular}

Activities were based on $0.01 \mathrm{~g}$ of $\mathrm{TiO}_{2}$ and with $300 \mathrm{~nm}$ light source.

ca. $0.14-0.58 \mathrm{eV}$ blue shift relative to anatase $\mathrm{TiO}_{2}$ powder $[53,54]$. The greater catalytic activities of TiPILC in comparison to powder $\mathrm{TiO}_{2}$ in photo-decomposition of 2-propanol and $n$-carboxylic acids were attributed to the particle size quantization effect [53]. However, controversial results were observed in regard to the degradation of organic pollutants in water. Table 3 compares the rates of $\mathrm{CO}_{2}$ formation over Ti-PILC and $\mathrm{TiO}_{2}$ powder in photo-degradation of several phenyl pollutants in water. Ti-PILC showed higher catalytic activities relative to $\mathrm{TiO}_{2}$ powder in complete degradation of hydrophobic pollutants such as benzene, chlorobenzene and 1,2-dichlorobenzene, while reverse results were observed for hydrophilic pollutants such as phenol. It is proposed that the pore structures of PILC may facilitate the photo-degradation reaction by adsorbing favorably the hydrophobic pollutant molecules onto the surface of silicate, where the active $\mathrm{TiO}_{2}$ microcrystallites were adjacent.

\section{Other layered compounds}

\subsection{Laminar metal oxides and their pillaring reactions}

The pillaring techniques are nowadays gradually employed to many compounds of laminar structures other than the naturally occurring and synthetic clays. This area of research has generated a number of new microporous materials with potential applications in catalysis.

Among the many pillared derivatives of metal oxides reported in the literature, only a very few of them was directly exchangeable with polyoxocations in aqueous solutions [55]. Most of these layered compounds were not swellable in water due to the high charge density on the basal layers. As a result, organic intercalated precursors with interlayer spacings widely expanded by organic species were used in order to facilitate the ion-exchange of bulky inorganic ions into the interlayer and to achieve homogeneous distribution of the inorganic pillars. Layer compounds with negative charges on the basal layers are most commonly encountered. Compounds in this category include aluminum free silicates $\left(\mathrm{H}_{4} \mathrm{Si}_{14} \mathrm{O}_{30} \cdot \mathrm{H}_{2} \mathrm{O}\right)$ [56,57], manganate $\left(\mathrm{Na}_{4} \mathrm{Mn}_{14} \mathrm{O}_{26}\right.$. $\left.x \mathrm{H}_{2} \mathrm{O}\right)$ [58-60], titanates $\left(\mathrm{Na}_{2} \mathrm{Ti}_{3} \mathrm{O}_{7}\right)$ [61-63] and $\mathrm{K}_{2} \mathrm{Ti}_{4} \mathrm{O}_{9}$ [64], niobate $\left(\mathrm{KNb}_{3} \mathrm{O}_{8}\right)$ [65] and $\left.\mathrm{Ca}_{2} \mathrm{Nb}_{3} \mathrm{O}_{10}\right)$ [66], titanoniobate $\left(\mathrm{KTiNbO}_{5}\right)$ [66] as well as zirconium and titanium phosphates [67]. In contrast, layered double hydroxides (LDH), also known as anionic clays, consist of positively charged brucitelike layers and charge-balancing gallery anions. A broad range of compositions in formula of $\left[\mathrm{M}(\mathrm{II})_{1-x} \mathrm{M}^{\prime}(\mathrm{III})_{x}(\mathrm{OH})_{2}\right]\left[\mathrm{A}^{n-}\right]_{x / n} \cdot y \mathrm{H}_{2} \mathrm{O} \quad(x=0.17-$ 0.33 ) is possible, wherein the $\mathrm{M}(\mathrm{II})$ and $\mathrm{M}^{\prime}$ (III) metal ions occupy octahedral positions in the hydroxide layers and $\mathrm{A}^{n-}$ is the exchangeable gallery anion.

Table 4 illustrates some of these pillared layered compounds with their corresponding physico-chemical properties. For the negative charged layered compounds, intercalation with alkylamines can usually expand the interlayer spacings to any desired distances. Then, polyoxocations such as aluminum Keggin's ion, $\left[\mathrm{Al}_{13} \mathrm{O}_{4}(\mathrm{OH})_{24}\left(\mathrm{H}_{2} \mathrm{O}\right)_{12}\right]^{7+}$, is introduced into the interlayer as pillar through cation exchange. On the other hand, the interlayer alkylammonia ions also serve as an hydrophobic phase to dissolve organic silicone reagents, which can be further transformed to silica pillar through hydrolysis and calcination. Similar idea was taken up by Hou et al. $[65,68]$, who used the silicone reagents containing amino functional group for direct intercalation with acid form of the 
Table 4

Some examples of pillared layer compounds and their properties

\begin{tabular}{|c|c|c|c|c|c|c|}
\hline Layer compound & $\begin{array}{l}\text { Organic precursor } \\
\left(n-\mathrm{C}_{n} \mathrm{H}_{2 n+1} \mathrm{NH}_{2}\right)\end{array}$ & $\begin{array}{l}\text { Pillar/pillar } \\
\text { precursor }\end{array}$ & $\begin{array}{l}\text { d-Spacing } \\
(\AA)\end{array}$ & $\begin{array}{l}\text { SA } \\
\left(\mathrm{m}^{2} \mathrm{~g}^{-1}\right)\end{array}$ & $\begin{array}{l}\text { Thermo-stability } \\
\left({ }^{\circ} \mathrm{C}\right)\end{array}$ & Reference \\
\hline \multirow[t]{2}{*}{ Magadiite $\mathrm{H}_{4} \mathrm{Si}_{4} \mathrm{O}_{30} \cdot \mathrm{H}_{2} \mathrm{O}$} & 8 & ${ }^{\mathrm{a}}$ TEOS & \multirow[t]{2}{*}{$20.7-25.9$} & $480-670$ & 500 & {$[56]$} \\
\hline & 6 & ${ }^{\mathrm{b}} \mathrm{Al}_{13}^{7+}$ & & 261 & 700 & {$[57]$} \\
\hline Na-Buserite $\mathrm{Na}_{4} \mathrm{Mn}_{14} \mathrm{O}_{26} \cdot x \mathrm{H}_{2} \mathrm{O}$ & 6 & $\mathrm{Al}_{13}^{7+}$ & 14 & 151 & 500 & [58-60] \\
\hline \multirow[t]{2}{*}{ Trititanate $\mathrm{Na}_{2} \mathrm{Ti}_{3} \mathrm{O}_{7}$} & \multirow[t]{2}{*}{8} & TEOS & 20 & 280 & 538 & {$[61]$} \\
\hline & & $\mathrm{Al}_{13}^{7+}$ & 19 & 105 & 500 & {$[62]$} \\
\hline Trititanate $\mathrm{Na}_{1.17} \mathrm{H}_{0.83} \mathrm{Ti}_{3} \mathrm{O}_{7}$ & 6 & $\mathrm{Al}_{13}^{7+}$ & 16.3 & 170 & 700 & {$[63]$} \\
\hline Tetratitanate $\mathrm{K}_{2} \mathrm{Ti}_{4} \mathrm{O}_{9}$ & 6 & $\mathrm{Al}_{13}^{7+}$ & 15.3 & 254 & 650 & {$[64]$} \\
\hline Niobate $\mathrm{KCa}_{2} \mathrm{Nb}_{3} \mathrm{O}_{10}$ & 8 & TEOS & 29.3 & 200 & 500 & {$[66]$} \\
\hline Niobate $\mathrm{KNb}_{3} \mathrm{O}_{8}$ & None & ${ }^{\mathrm{c}}$ APTES & 15.8 & 165 & 600 & {$[65]$} \\
\hline Titanoniobate $\mathrm{KTiNbO}_{5}$ & None & APTES & 12 & 70 & 750 & {$[68]$} \\
\hline Molybdate $\mathrm{Li}_{x} \mathrm{MoO}_{3} \cdot y \mathrm{H}_{2} \mathrm{O}$ & None & $\mathrm{Al}_{13}^{7+}$ & 15.2 & 107 & 400 & [54] \\
\hline Titanium phosphate $\alpha-\mathrm{Ti}\left(\mathrm{HPO}_{4}\right)_{2}$ & 4 & $\mathrm{Al}_{13}^{7+}$ & 16.1 & 183 & 400 & [67] \\
\hline $\mathrm{LDH} \mathrm{Zn}_{24} \mathrm{Al}_{8}(\mathrm{OH})_{64}\left(\mathrm{NO}_{3}\right)_{8}$ & None & $\alpha-\left[\mathrm{SiW}_{11} \mathrm{O}_{39}\right]^{8-}$ & 14.6 & 97 & & [69] \\
\hline $\mathrm{Mg}_{4} \mathrm{Al}_{2}(\mathrm{OH})_{12}\left(\mathrm{NO}_{3}\right)_{2}$ & ${ }^{\mathrm{d}} 6$ & $\left(\mathrm{NH}_{4}\right)_{2} \mathrm{~B}_{4} \mathrm{O}_{7}$ & 14.2 & 75 & 550 & {$[71-73]$} \\
\hline
\end{tabular}

${ }^{\mathrm{a}} \mathrm{TEOS}=\mathrm{Si}\left(\mathrm{OC}_{2} \mathrm{H}_{5}\right)_{4}$.

${ }^{\mathrm{b}} \mathrm{Al}_{13}^{7+}=\left[\mathrm{Al}_{13} \mathrm{O}_{4}(\mathrm{OH})_{24}\left(\mathrm{H}_{2} \mathrm{O}\right)_{12}\right]^{7+}$.

${ }^{\mathrm{c}} \mathrm{APTES}=\mathrm{NH}_{2}\left(\mathrm{CH}_{2}\right)_{3} \mathrm{Si}\left(\mathrm{OC}_{2} \mathrm{H}_{5}\right)_{3}$.

${ }^{\mathrm{d}}$ Adipic acid.

layered metal oxides. The silicone reagents were further transformed to silica pillars after calcination.

\subsection{Physico-chemical properties and catalytic applications}

With proper preparation methods, the pillared derivatives of laminar metal oxides were reported to own porous structures and high surface area. Similar to that of pillared clays, the pillar species usually introduce new chemical functionality onto the materials. For example, Al-pillared derivatives generally showed higher acidity than either Si-pillared or their pristine layered compounds [57]. Moreover, the original chemical properties of the basal layers are retained after pillaring. For instance, Al-pillared buserite (a layered manganate) provides higher active surface area participating in catalytic redox reactions than Na-buserite [60]. In an oxygen-rich environment, complete combustion of ethane was achieved at $350^{\circ} \mathrm{C}$ over $\mathrm{Al}-$ buserite, and the pillared structure retained. However, the pillared structure was less stable in an oxygen-poor environment due to the high reactivity of the lattice oxygen of buserite. More examples can be found in the literature. Pt supported on Al-pillared titanate retained the character of strong metal-support interaction similar to that observed on $\mathrm{TiO}_{2}$ support [63]. Pt loading on
Si-pillared niobate catalyst was efficient in photocatalytic decomposition of alcohols [66].

For the positive-charged layered double hydroxide compounds, LDHs have been pillared with polyoxoanions of tungsten, molybdenum, vanadium $[69,70]$ and borates $[71,72]$ through ion-exchange with the organic expanded precursors. The polyoxometallates of groups VB and VIB are interesting for their possible applications as oxidation catalysts. For example, vanadium-pillared LDH was used in dehydrogenation of $p$ methyl(3-methylethyl)-benzene [70]. However, most of these polyoxometallate species are stable in acid environment and tend to decompose when pillared in between the basic double hydroxide layers. In contrast, tetraborate anion, which is stable in mild basic environment, seems to give best thermostability among the pillars been used. The borate-pillared LDH was found to own both acidic and basic functionalities and could catalyze reactions such as aldol condensation and Backmann rearrangement of cyclohexanone oxime [73].

\section{Layered compounds as precursors for preparing supported monolayer catalysts}

Many of the organic expanded laminar compounds can disperse in nonaqueous solutions as separated 
Table 5

Effect of vanadia precursor on the performance of $\mathrm{VO}_{x} / \mathrm{TiO}_{2}$ catalysts in oxidation of toluene

\begin{tabular}{|c|c|c|c|c|c|}
\hline \multirow[t]{2}{*}{ Catalyst } & \multirow[t]{2}{*}{ Toluene conversion $\left(10^{-5} \mathrm{~mol} \min ^{-1} \mathrm{~g} \mathrm{~V}_{2} \mathrm{O}_{5}\right)$} & \multicolumn{4}{|c|}{ Conversion to product $\left(10^{-5} \mathrm{~mol} \mathrm{~min}^{-1} \mathrm{~g} \mathrm{~V}_{2} \mathrm{O}_{5}\right)$} \\
\hline & & Benzaldehyde & Benzoic acid & $\mathrm{CO}$ & $\mathrm{CO}_{2}$ \\
\hline $0.7 \%-\mathrm{L}^{\mathrm{a}}$ & 14.6 & 8.1 & 0.83 & 0.92 & 4.8 \\
\hline $1.4 \%-\mathrm{L}$ & 17.5 & 3.5 & 1.0 & 2.5 & 10.5 \\
\hline $7 \%-\mathrm{L}$ & 19.7 & 2.0 & 8.5 & 2.3 & 6.9 \\
\hline $0.7 \%-\mathrm{A}^{\mathrm{b}}$ & 14.2 & 8.0 & 0.60 & 0.84 & 4.8 \\
\hline $1.4 \%-\mathrm{A}$ & 2.3 & 1.5 & 0 & 0 & 0.82 \\
\hline $7 \%-\mathrm{A}$ & 29.7 & 2.4 & 17 & 2.2 & 8.1 \\
\hline
\end{tabular}

${ }^{a}$ Catalysts prepared with amine-intercalated $\mathrm{V}_{2} \mathrm{O}_{5}$ in ethanol.

${ }^{\mathrm{b}}$ Catalysts prepared with ammonium vanadate in oxalic acid.

Reaction temperature $=270^{\circ} \mathrm{C} ; \mathrm{O}_{2} /$ toluene $\mathrm{mol}$ ratio $=10$; contact time of toluene $=0.46 \mathrm{~min} \mathrm{~g} \mathrm{catal} \mathrm{ml}^{-1}$.

sheets. Therefore, they can serve as precursors to prepare supported catalysts of monolayer coverage. An example was given on supported vanadia catalysts. An amine-intercalated layered vanadium oxide was prepared from a mixture of $n$-alkylamines, a small amount of water and $\mathrm{V}_{2} \mathrm{O}_{5}$ powder [74]. This compound was found to form monolayer dispersion in alcohol. Hence, a preliminary comparison was made on the performance of $\mathrm{V}_{2} \mathrm{O}_{5} / \mathrm{TiO}_{2}$ catalysts prepared with amine-intercalated $\mathrm{V}_{2} \mathrm{O}_{5}$ in ethanol and those from ammonium vanadate dissolved in oxalic acid. In toluene oxidation reaction, products obtained were benzaldehyde, benzoic acid, $\mathrm{CO}$ and $\mathrm{CO}_{2}$. The catalysts prepared with layered vanadium oxide and those prepared with ammonium vanadate showed similar activities at low $\mathrm{V}_{2} \mathrm{O}_{5}$ loading (Table 5). But as the loading increases, the catalyst prepared with ammonium vanadate tend to give higher conversion and higher selectivity of benzoic acid. Further investigation about the structure of vanadium species prepared from different sources is undergoing. Nevertheless, these results demonstrate that organic intercalated laminar compounds can provide an alternative route for preparing supported monolayer catalysts.

\section{Transformation of layer compounds to channel-pore materials}

In 1992, workers at Mobil discovered the preparation of a series of novel, mesoporous materials (designated M41S) [75,76]. One member of this series, MCM-41, which possesses a hexagonal arrangement of uniformly sized mesopores, with tunable diameter varied from 15 to $100 \AA$, have attracted considerable attention. Potential applications of these materials include catalytic reactions of large molecules, formation of organic-inorganic nanocomposites and biomimetics. A liquid crystal templating mechanism was proposed for the formation of MCM-41 [75,76]. However, MCM-41 is not the first silica molecular sieve of ordered mesopores reported in the literature. Yanagisawa et al. [77] in 1988 made similar mesoporous materials with narrow-pore-size distributions and somewhat similar physico-chemical properties as MCM-41 from a thin layer silicate, named kanemite. A folded-sheets mechanism was proposed and the porous material was briefly named as FSM (an abbreviation of folded-sheet mesoporous materials) [78]. Chen et al. [79] did a detailed study on the mechanism and concluded that MCM-41 and FSM-16 were formed by different mechanisms. They also proposed that the kanemite sheets were reorganized to form hexagonal mesophase under the influence of the polar head group of exchanged surfactant cations. Recently, a novel layered aluminophosphate compound of kanemite-like structure was prepared in our laboratory [80]. Similar transformation of the thin sheet structure to ordered mesopores in the presence of surfactant cations was also observed.

The transformation of sheet structures to ordered porous materials was found in geological system more than a decade ago. Among the abundant crystal structures of manganese oxide widely distributed in soils and sediments, both layered and channel structures are known. Golden and co-workers [81] were the first to report the transformation of layered manganese oxide, named birnessite, to ordered $2 \times 2$ and $3 \times 3$ channel 
pore structures of octahedral $\mathrm{MnO}_{6}$ units under hydrothermal condition. Detailed study of the effect of interlayer cations on the diameter of channel pores was carried out by Shen et al. [82]. Recently, mesoporous structures of manganese oxide were also prepared by oxidizing a layered phase of $\mathrm{Mn}(\mathrm{OH})_{2}$ in the presence of cationic surfactants [83]. Although the detailed mechanism was not clear yet, these mesoporous octahedral molecular sieves of manganese oxide were reported to be active in catalytic oxidation of alkanes to alcohols and ketones.

\section{Conclusions}

Layer compounds have been used as catalysts in many reactions, and new development in transformation of layer compounds to novel catalytic materials is emerging. Acid-treated, ion-exchanged and metal salts-loaded clays demonstrate high efficiency and product selectivity in acid catalyzed organic reactions, attributed to that the reactant molecules are constrained by adsorption in two-dimensional domain. Pillared clays (PILCs) which own larger pores than zeolites were found efficient in cracking large molecules in crude oil. The hydrothermal stability of pillared clays was the key problem in preventing PILCs from practical application in cracking process. However, this was reported to be solved by using rectorite clay of thicker basal layer as starting material. On the other hand, Al-, Zr-, $\mathrm{Fe}-$ and Cr-PILCs with pore diameters usually greater than $8 \AA$ have been applied in processes, in which both acidity and accessibility are required, for manufacture of fine chemicals of large molecular size. Moreover, PILCs with polyoxocations of active transition metals were found to enhance catalytic activities in redox processes and in photocatalytic reactions. The pillaring technique has also been employed to many other layered metal oxides with either positive or negative charged basal layers. By varying the chemical composition of the pillar and the basal layer, many new materials with distinguished catalytic properties were generated. Another important development of layer compounds is their possibility in transformation to ordered channel-pore materials. Layered compounds of thin basal sheets were reported to fold into micropores or mesopores of ordered tunnels under the influence of interlayer template species. This route provides a way to prepare ordered porous materials that are difficult to obtain by direct synthesis. Finally, many of the organic expanded laminar compounds, which can disperse in nonaqueous solutions as isolated sheets, can serve as precursors for preparing supported monolayer catalysts. The last two areas of research are still new, and they should be a focus for future studies.

\section{Acknowledgements}

The author wishes to express best thanks to many associates and students who have worked on various aspects of the layer compounds over the years: Drs. She-Tin Wong, Jenn-Tsuen Lin, Shi-Jane Tsai, SungJeng Jong, Bo-Ya Hsu, and Mr. Tzun-Chin Wang, Shen-Hwa Wong, Jeng-Ning Tzeng, Chi-Fu Chang, Kuo-Chan Weng, Yu-Jen Chen and Ms. Yi-Fen Lee, Sheng-Fen Chiu. The constant financial support from National Science Council, Taiwan, is also gratefully acknowledged.

\section{References}

[1] H.H. Voge, in: B.H. David, W.P. Hettinger (Eds.), Heterogeneous Catalysis, Selected American Histories, ACS Symposium Series, no. 222, 1983, p. 235.

[2] H.E. Swift, in: J.T. Burton, R.L. Garten (Eds.), Advanced Material in Catalysis, Academic Press, New York, 1977, p. 209.

[3] M.L. Occelli, R.J. Rennard, Catal. Today 2 (1988) 309.

[4] S.M. Csicsery, Zeolites 4 (1984) 202.

[5] P. Laszlo, Acc. Chem. Res. 19 (1986) 121.

[6] L. Delaude, P. Laszlo, K. Smith, Acc. Chem. Res. 26 (1993) 607.

[7] D.E.W. Vaughan, Catal. Today 2 (1988) 187.

[8] D.E.W. Vaughan, P.K. Maher, E.W. Albers, US Patent 3838037 (1974).

[9] R. Parthasarthy, D.E.W. Vaughan, British Patent, 1483466 (1974).

[10] R. Burch (Ed.), Pillared Clays, Catal. Today 2 (1988).

[11] F. Figueras, Catal. Rev. Sci. Eng. 30 (1988) 457.

[12] A.F. Wells, Structural Inorganic Chemistry, 5th ed., Clarendon Press, Oxford, 1987, p. 30.

[13] J.M. Thomas in: M.S. Whittingham, A.J. Jacobson (Eds.), A Intercalation Chemistry, Academic Press, New York, 1980 p. 55.

[14] Y. Morikawa, Adv. Catal. 39 (1993) 303.

[15] P. Laszlo, Pure and Appl. Chem. 62 (1990) 2027.

[16] T.T. Upadhya, T. Daniel, A. Sudalai, T. Ravindranathan, K.R. Sabu, Synth. Comm. 26 (1996) 4539. 
[17] P. Laszlo, J. Vandormael, Chem. Lett. (1988) 1843.

[18] J.H. Clark, A.P. Kybett, D.J. Macquarrie, S.J. Barlow, P. Landon, J. Chem. Soc., Chem. Commun. (1989) 1353.

[19] C. Cativiela, J.I. Garcia, M. Garcia-Matres, J.A. Mayoral, F. Figueras, J.M. Fraile, T. Cseri, B. Chiche, Appl. Catal. 123 (1995) 273.

[20] A. Cabrera, D. Vazquez, L. Velasco, M. Salmon, J. Molecular Catal. 75 (1992) 101.

[21] D.E.W. Vaughan, R.J. Lussier, in: L.V.C. Rees (Ed.), Proceedings of Fifth Intermational Conference on Zeolites, Heyden, London, 1980, p. 94.

[22] D.E.W. Vaughan, Ind. Eng. Chem. Prod. Res. Der. 22 (1983) 553.

[23] M.L. Occelli, Catal. Today 2 (1988) 339.

[24] M.L. Occelli, R.A. Innes, F.S.S. Hwu, J.W. Hightower, Appl. Catal. 14 (1985) 69

[25] E. Kikuch, T. Matsuda, J. Ueda, Y. Morita, Appl. Catal. 16 (1985) 401

[26] R. Burch (Ed.), Catal. Today 2 (1988).

[27] A. Corma, Chem. Rev. 97 (1997) 2373.

[28] R.M. Barrer, Zeolites and Clay Minerals as Sorbents and Molecular Sieves, Academic Press, London, 1978.

[29] M.M. Mortland, V.E. Berkheiser, Clays Clay Miner. 24 (1976) 60.

[30] J. Guan, E. Min, Z. Yu, US Patent 4757040 (1987).

[31] J. Guan, E. Min, Z. Yu, Eur. Patent 88300815 (1986).

[32] J. Guan, E. Min, Z. Yu, H. Zheng, Y. Liang, China-Japan-US Symp. Heterog. Catal. Relat. Energy Probl., BO2C, 1982, p. 7.

[33] D. Tichit, F. Fajula, F. Figueras, J. Bousquet, C. Gueguen, in: B. Imelik et al. (Eds.), Catalysis by Acids and Bases, Elsevier, Amsterdam, 1985, p. 351.

[34] M. Tokarz, J. Shabtai, Clays Clay Miner. 33 (1985) 89.

[35] J.W. Ward, in: J.A. Rabo (Ed.), Zeolite Chemistry and Catalysis, Chapter 3, ACS Monograph 171, 1976.

[36] T. Matsuda, M. Matsukata, E. Kikuchi, Y. Morita, Appl. Catal. 21 (1986) 297.

[37] T. Matsuda, M. Asanuma, E. Kikuchi, Appl. Catal. 38 (1988) 289.

[38] J. Shabtai, N. Lahav, US Patent 4216188 (1980).

[39] K. Lourvanij, G.L. Rorrer, Appl. Catal. 109 (1994) 147.

[40] K. Lourvanij, G.L. Rorrer, Ind. Ing. Chem. Res. 32 (1993) 19.

[41] T. Mishra, K.M. Parida, J. Molecular Catal. A 121 (1997) 91.

[42] S.-J. Jong, J.-T. Lin, S. Cheng, in: T. Hattori and T. Yashima (Eds.), Zeolites and Microporous Crystals, Kodansha, Tokyo, 1994, p. 33.

[43] T.J. Pinnavaia, M.S. Tzou, S.D. Landau, J. Am. Chem. Soc. 107 (1985) 4783.

[44] S.D. Landau, J.A. Hinnenkamp, US Patent, 5035787 (1991).

[45] E.P. Giannelis, E.G. Rightor, T.J. Pinnavaia, J. Am. Chem. Soc. 110 (1988) 3880.

[46] S.J. Jong, J.T. Lin, S. Cheng, in: Zeolites and Microporous Crystals, Kodansham, Japan, 1994, p. 33.

[47] S.G. Kukes, R.L. Banks, J.R. Harris, US Patent, 4879425 (1989).

[48] J.T. Yang, J.P. Chen, E.S. Kikkinides, L.S. Cheng, Ind. Eng. Chem. Res. 31 (1992) 1440.
[49] J.T. Kloprogge, W.J.J. Welters, E. Booy, V.H.J. de Beer, R.A. Van Santen, J.W. Geus, J.B.H. Jansen, Appl. Catal. 97 (1993) 77.

[50] B.M. Choudary, V.L.K. Valli, J. Chem. Soc., Chem. Commun. (1990) 1115.

[51] B.M. Choudary, V.L.K. Valli, A. Durga Prasad, J. Chem. Soc., Chem. Commun. (1990) 721.

[52] B.M. Choudary, A. Durga Prasad, V Bhuma, V. Swapna, Org. Chem. 57 (1992) 5841.

[53] H. Yoneyama, S. Haga, S. Yamanaka, J. Phys. Chem. 93 (1989) 4833.

[54] S. Cheng, S.-J. Tsai, Y.-F. Lee, Catal. Today 26 (1995) 87.

[55] L.F. Nazar, S.W. Liblong, X.T. Yin, J. Am. Chem. Soc. 113 (1991) 5889.

[56] J.S. Dailey, T.J. Pinnavaia, Chem. Mater. 4 (1992) 855.

[57] S.-T. Wong, S. Cheng, Chem. Mater. 5 (1993) 770.

[58] S.-T. Wong, S. Cheng, Inorg. Chem. 31 (1992) 1165.

[59] S.-T. Wong, S. Cheng, J. Thermal Anal. 40 (1993) 1181.

[60] S.-T. Wong, S. Cheng, J. Chin. Chem. Soc. 40 (1993) 509.

[61] M.E. Landis, B.A. Aufdembrink, P. Chu, I.D. Johnson, G.W. Kirker, M.K. Rubin, J. Am. Chem. Soc. 113 (1991) 3189.

[62] M.W. Anderson, J. Klinowski, Inorg. Chem. 29 (1990) 3260.

[63] S.-J. Tsai, S.-J. Jong, L.-S. Du, S. Cheng, Microporous Mater. 2 (1994) 185.

[64] S. Cheng, T.-C. Wang, Inorg. Chem. 28 (1989) 1283.

[65] W. Hou, B. Peng, Q. Yan, X. Fu, G. Shi, J. Chem. Soc., Chem. Commun. (1993) 253.

[66] K. Domen, Y. Ebina, T. Sekine, A. Tanaka, J. Kondo, C. Hirose, Catal. Today 16 (1993) 479.

[67] A. Clearfield, B.D. Roberts, Inorg. Chem. 27 (1988) 3237.

[68] W. Hou, J. Ma, Q. Yan, X. Fu, J. Chem. Soc., Chem. Commun. (1993) 1144.

[69] E. Narita, P.D. Kaviratna, T.J. Pinnavaia, J. Chem. Soc., Chem. Commun. (1993) 60.

[70] M.A. Drezdzon, E.J. Moore, M.P. Kaminsky, US Patent 4843168 (1989).

[71] S. Cheng, J.-T. Lin, in: M.L. Occelli, H.E. Robson (Eds.), Synthesis of Microporous Materials, Van Nostrand Reinhold, New York, 1992, p. 170.

[72] A. Bhattacharya, D.B. Hall, Inorg. Chem. 31 (1992) 3869.

[73] L.-T. Lin, Ph.D. dissertation, National Taiwan University, Taipei, Taiwan, 1993.

[74] S. Cheng, H.-D. Hwang, G.E. Maciel, J. Molecular Structure, in press.

[75] C.T. Kresge, M.E. Leonowicz, W.J. Roth, J.C. Vartuli, J.S. Beck, Nature 359 (1992) 710.

[76] J.S. Beck, J.C. Vartuli, W.J. Roth, M.E. Leonowicz, C.T. Kresge, K.D. Schmitt, C.T.-W. Chu, D.H. Olson, E.W. Sheppard, S.B. McCullen, J.B. Higgins, J.L. Schlenker, J. Am. Chem. Soc. 114 (1992) 10834.

[77] T. Yanagisawa, T. Shimizu, K. Kuroda, C. Kato, 56th National Meeting of the Chemical Society of Japan, Tokyo, April 1988, Abstr. I, p. 761, no. IXIID42. 
[78] T. Yanagisawa, T. Shimizu, K. Kuroda, C. Kato, Bull. Chem. Soc. Jpn. 63 (1990) 1535.

[79] C.-Y. Chen, S.-Q. Xiao, M.E. Davis, Microporous Mater. 4 (1995) 1.

[80] S. Cheng, J.-N. Tzeng, B.-Y. Hsu, Chem. Mater. 9 (1997) 1788.
[81] D.C. Golden, C.C. Chen, J.B. Dixon, Science 231 (1986) 717.

[82] Y.-F. Shen, S.L. Suib, C.-L. O'Young, J. Am. Chem. Soc. 116 (1994) 11020.

[83] Z.-R. Tian, W. Tong, J.-Y. Wang, N.-G. Duan, V.V. Krishnan, S.L. Suib, Science 276 (1997) 926. 